\title{
Does predator benefits prey? Commensalism between Corynoneura Winnertz (Diptera, Chironomidae) and Corydalus Latreille (Megaloptera, Corydalidae) in Southeastern Brazil
}

\author{
Marcos Callisto, ${ }^{1}$; Michael D.C. Goulart '; Pablo Moreno ${ }^{1} \&$ Rogério P. Martins ${ }^{2}$ \\ 1 Departamento de Biologia Geral, Instituto de Ciências Biológicas, Universidade Federal de Minas Gerais. Caixa Postal 486, \\ 30161-970, Belo Horizonte, Minas Gerais, Brasil. \\ 2 Corresponding author.
}

\begin{abstract}
Commensalism between Corydalus Latreille, 1802 (Megaloptera, Corydalidae) and Corynoneura Winnertz, 1846 (Diptera, Chironomidae, Orthocladiinae) larvae was recorded in Indaiá stream, at 1,380 m a.s.l. (Parque Nacional da Serra do Cipó, $19^{\circ}-20^{\circ} \mathrm{S}, 43^{\circ}-44^{\circ} \mathrm{W}$ ) and in the headwaters of São Francisco river, at 1,300-1,700 $\mathrm{m}$

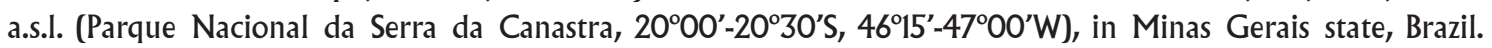
Seventy eight Corydalus larvae (range $22-88 \mathrm{~mm}$ ) were sampled: 61 in the Indaiá stream and 17 in other two streams. Twelve Corydalus larvae $(22-79 \mathrm{~mm})$ in the Indaiá stream and three out of 15 larvae in the headwaters of São Francisco river $(38-50 \mathrm{~mm})$ had Corynoneura, larvae and pupae on their gills $\left(3^{\text {rd }}\right.$ to $\left.6^{\text {th }}\right)$ and a few larvae attached to the abdominal segments of larger Corydalus larvae (> $25 \mathrm{~mm})$. Sixty-nine larvae of Corynoneura were found in the regurgitated material from Corydalus. It is remarkable that by attaching to larger body size predators, prey could become free from predator bouts and could also be transported by them.
\end{abstract}

KEY WORDS. Headwater stream; phoresy; predator-prey relationship; São Francisco river.

RESUMO. O predador beneficia sua presa? Comensalismo entre Corynoneura Winnertz (Diptera, Chironomidae) e Corydalus Latreille (Megaloptera, Corydalidae) no Sudeste do Brasil. Comensalismo entre Corydalus Latreille, 1802 (Insecta, Megaloptera, Corydalidae) e Corynoneura Winnertz, 1846 (Insecta, Diptera, Chironomidae, Orthocladiinae) foi registrado no córrego Indaiá situado a $1.380 \mathrm{~m}$ de altitude no Parque Nacional da Serra do Cipó $\left(19-20^{\circ} \mathrm{S}, 43-44^{\circ} \mathrm{W}\right)$ e nas nascentes do rio São Francisco a $1.300-1.700 \mathrm{~m}$ de altitude no Parque Nacional da Serra da Canastra $\left(20^{\circ} 00^{\prime}-20^{\circ} 30^{\prime} \mathrm{S}, 46^{\circ} 15^{\prime}-47^{\circ} 00^{\prime} \mathrm{W}\right)$, Minas Gerais, Brasil. Setenta e oito larvas de Corydalus (tamanhos: 22-88 mm) foram coletadas: 61 no córrego Indaiá e 17 em outros córregos. Doze larvas de Corydalus (tamanhos: 22-79 mm) no córrego Indaiá e três encontradas nas nascentes do rio São Francisco (tamanhos: 38$50 \mathrm{~mm}$ ) apresentaram larvas e pupas de Corynoneura em suas brânquias ( $3^{\mathrm{a}}$ a $6^{\mathrm{a}}$ ) e algumas larvas fixadas nos segmentos abdominais de grandes Corydalus (> $25 \mathrm{~mm}$ ). Sessenta e nove larvas de Corynoneura foram retiradas do material regurgitado por Corydalus. É importante observar que fixados aos predadores de grande tamanho corporal as presas se tornam livres de outros predadores além de serem transportados por eles.

PALAVRAS-CHAVE. Foresia; relação predador-presa; rios de cabeceira; rio São Francisco.

Commensalism has received less attention from ecologists than competition, predation and parasitism. Associations between chironomids and their hosts have been often interpreted as commensalisms, whereby the chironomid derives certain advantages from its association with its host, while the host is unharmed but derives nothing in return (PenNuto et al. 2002). RoQue et al. (2004) emphasized an increasing number of studies on this subject in the Neotropical region, but the knowledge about these ecological interactions is fragmented and no summary of information is available. Chironomid-host associations have involved symbioses, including parasitism (JACOBSEN 1998) and symphoresy (DE la Rosa 1992, Pennuto 1997). Commensalism and phoretic associations have been also reported between Chironomidae and a variety of aquatic macroinvertebrates including Trichoptera (Steffan 1967), Ephemeroptera (Callisto \& Goulart 2000), Plecoptera (StefFan 1967, Dorvillé et al. 2000), Hemiptera (Roback 1977), Odonata (Rosenberg 1972), Megaloptera (Furnish et al. 1981, Pennuto 1998, 2000, 2003, De la Rosa 1992) and snails (Mancini 1979). Nevertheless, some authors assume that phoresy is relatively uncommon among chironomids (e.g. WHITE et al. 1980), while others argued for the opposite (e.g. Rоваск 1977).

This paper describes commensalism between Corydalus and Corynoneura. We tested the hypothesis that Corydalus body size influences the occurrence and numbers of commensal Corynoneura larvae and pupae that could be attached to their bodies.

Revista Brasileira de Zoologia 23 (2): 569-572, junho 2006 


\section{MATERIAL AND METHODS}

Seven stream sections (ranging from $2^{\text {nd }}$ to $7^{\text {th }}$ order and between 1,300-1,700 m a.s.1.), 6 located in Doce River basin, Cardeal Mota and Jaboticatubas municipalities, Serra do Cipó National Park (19 $\left.2^{\prime}-34^{\prime}, 43^{\circ} 27^{\prime}-38^{\circ} \mathrm{W}\right)$; and one headwater stream in São Francisco River basin, São Roque de Minas village, Serra da Canastra National Park $\left(20^{\circ} 00^{\prime}-20^{\circ} 30^{\prime} S, 46^{\circ} 15^{\prime}\right.$ $\left.47^{\circ} 00^{\prime} \mathrm{W}\right)$, Minas Gerais State, Southeastern Brazil were sampled. These are black-water streams, acidic ( $\mathrm{pH}$ 4.0-5.0), well oxygenated (> $90 \%$ saturation), with low electrical conductivity $\left(<150 \mathrm{mS} / \mathrm{cm}\right.$ ), and low nutrient contents (e.g., ${\mathrm{P}-\mathrm{PO}_{4}<10 \mu \mathrm{g} /}$

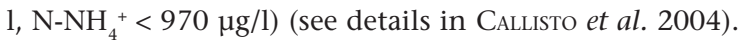

Megaloptera larvae were collected manually in rainy (November-March) and dry (May-September) seasons from 19931997 and 1999-2000, following a stream order $\left(2^{\text {nd }}-7^{\text {th }}\right)$ longitudinal gradient along Indaiá stream, Peixe river (Doce river watershed) and from headwaters of the São Francisco river watershed (a $2^{\text {nd }}$ order reach). The two most representative substrates (gravel and sand, leaves and branches of riparian vegetation) were sampled along each river stretch totaling 252 samples (18 samples in each sampling period, two times per year in rainy and dry seasons). Samples were taken using a Surber sampler $\left(0.250 \mathrm{~mm}\right.$ mesh) with an area of $0.0625 \mathrm{~m}^{2}$ and additional qualitative samples were collected in all studied ecosystems by using hand nets $(0.250 \mathrm{~mm}$ mesh) from which Corydalids were sorted.

Five Corydalus specimens with no attached chironomids larvae and pupae were placed in vials with $10 \%$ formalin in order to induce regurgitation. Abdominal gills of Corydalus larvae were also checked for chironomids presence in laboratory. Eggs were counted by direct observations. Commensal larvae of Corynoneura attached to Corydalus bodies were sorted out from their hosts, mounted in slides, identified, preserved in $70 \%$ alcohol and deposited in the Collection of Benthic Macroinvertebrates of the Institute of Biological Sciences, Federal University of Minas Gerais.

\section{RESULTS AND DISCUSSION}

Seventy-eight Corydalus larvae were collected, 16 of which hosted Corynoneura (eggs $=16$, larvae $=145$, and pupae $=29$ ). Body length of Corydalus larvae ranged from 22 to $88 \mathrm{~mm}$, with a $40-50 \mathrm{~mm}$ modal class. Amongst the 16 larvae of Corydalus carrying commensals, 1 up to 33 Corynoneura larvae were found per individual (Corydalus body size between 30 and $88 \mathrm{~mm}$ ). Corynoneura larvae were attached mainly to abdominal segments and under gills (Tab. I). Eggs and pupae of Corynoneura were found only ventrally under gills and on the $1^{\text {st }}$ to $4^{\text {th }}$ abdominal segments, on both sides of the host. Differences between the location of attachment of larvae versus eggs and pupae were not found. Up to five pupae were found once on the same larva of Corydalus. These results reinforce DE LA Rosa (1992), Tokeshi (1999), and Roque et al. (2004) claims that amongst the insects, Megaloptera is one of the most frequent host group, together with Plecoptera, Ephemeroptera and Odonata. Bigger low mobile cryptic benthic species are also pointed out as responsible for their suitability as hosts. The same authors assume that this interaction might benefit the chironomids by decreasing predation risks, increasing mobility, improving protection from disturbances, improving opportunity to feed, and eliminating metabolic waste. Nevertheless, information on natural environments concerning prey preferences, foraging behavior, and life history characteristics may be involved, but are still unavailable to the Neotropics.

Filamentous algae were found attached to the dorsal proleg filaments on the abdomen of two Corydalus larvae. Observations under a dissecting microscope showed Corynoneura larvae among the algae. Larval position on the host seems not to vary with the developmental stage of the chironomid $\left(1^{\text {st }}-2^{\text {nd }}\right.$ larvae group versus $3^{\text {rd }}, 4^{\text {th }}$, and pupae, $\left.\chi^{2}=19.35, \mathrm{p}>0.05\right)$. Our data suggest there is no evidence of intraspecific competition for certain positions on hosts. Therefore there are no apparent benefits for occupying a particular site on host body.

The regurgitated gut contents from five Corydalus larvae (58-83 $\mathrm{mm}$ body size) from Indaiá stream ( $5^{\text {th }}$ order reach) in February 2000, yields sixty-nine Corynoneura larvae (10, 25, 7, 13,14 in each). It is supposed that eaten Corynoneura were directly taken from their preferred stream substrates (filamentous algae, mosses and debris), since those attached to the Corydalus larvae were unavailable as prey.

Commensal relationships between Corynoneura and Corydalus were relatively common in sandy bottom streams, such as in the Indaiá stream ( $2^{\text {nd }}$ up to $6^{\text {th }}$ order stretches) and in the Peixe river ( $7^{\text {th }}$ order stretch). Previous studies on stream ecosystems in the headwaters of Serra do Cipó and Serra da Canastra National Parks showed that Corynoneura was very abundant (GALDEAN et al. 1999b, 2001). Corynoneura was normally found on surfaces covered by filamentous algae, mosses and debris (GaldeAn et al. 1999 a, b). The Corynoneura Megaloptera host colonizing behavior is unknown. DE LA RosA (1992) suggested that drifting Thienemanniella Kieffer, 1911 could settle on the substrates and actively seek megalopteran larvae. HAYASHI (1988) suggested that large megalopterans tend to prey on insects much larger than chironomids and thus, the size of the megalopteran used as a host by the chironomids seem to diminish the risk of becoming prey.

Bigger Corydalus larvae had higher numbers of larvae and pupae of Corynoneura $\left(\mathrm{R}^{2}=0.752, \mathrm{p}<0.05\right)$. The location of eggs, larvae and pupae on the gills suggests that eggs can be laid on the water and then drift to Corydalus gills, where the Corynoneura life cycle takes place. This association only occurs on larger Corydalus larvae (> $20 \mathrm{~mm}$ ), in headwater streams probably because: 1 ) larger larva are more active predators than smaller ones, showing fast movements and higher amount of prey ingestion; 2) the greater trophic resources are (greater surface area, larger surface structures) associated with a larger host 


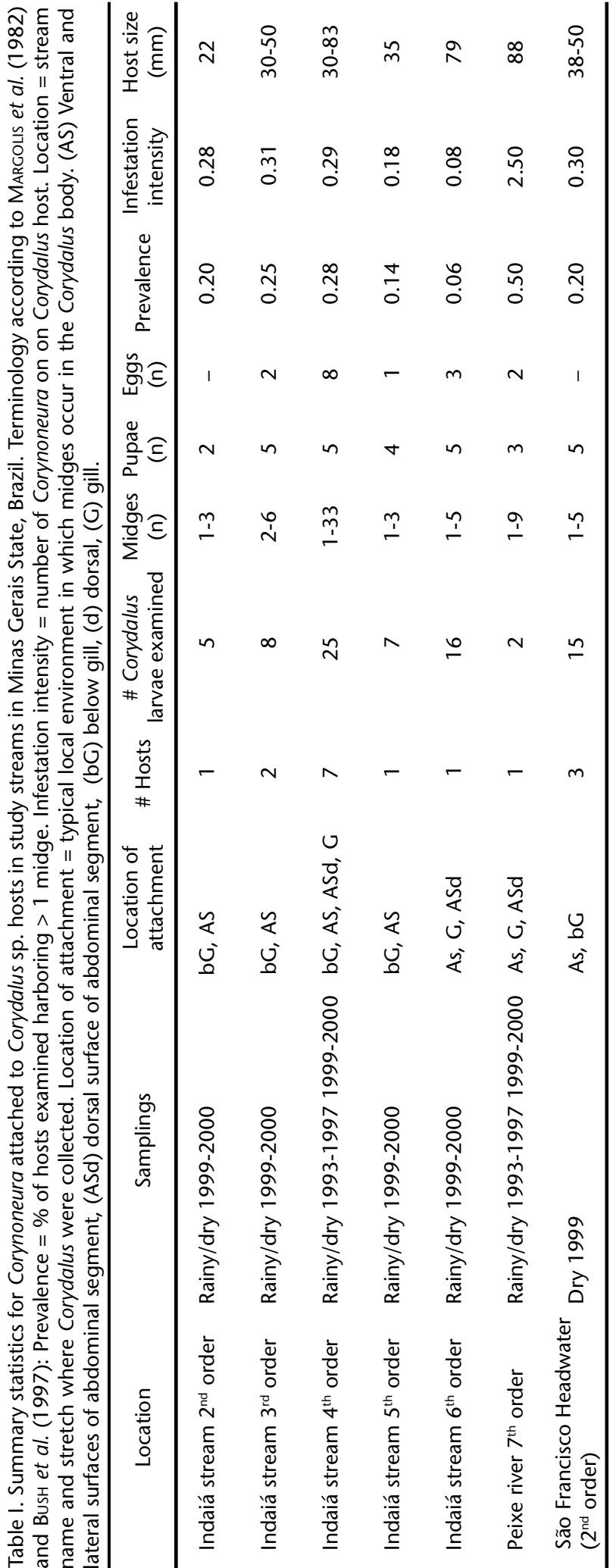

(TоKеSH 1986); 3) larger hosts are larger "islands" for drifting or searching larvae (TокеSHI 1986). Alternatively, Corydalus larvae may search for prey in those microhabitats where eggs, larvae and pupae of Corynoneura are. Sediment then is lifted from the substrate into the water column and Corynoneura may attach to the gills or abdominal segments of Corydalus (JACOBSEN 1998). Corynoneura larvae may also actively seek Corydalus larvae, larger Corydalus larvae may release a stronger chemical or physical cue for searching larvae than smaller larvae (Svensson 1979). Corydalus gills seem to be a safe site for Corynoneura development (out of predation pressure). We believe that the use of isotopic comparisons would confirm this commensal relationship in studied streams and rivers. Alternatively, it could clarify if Corynoneura were functioning as parasites, as proposed by Doucetr et al. (1999), when attached chironomids feed directly on the host rather than on detritus.

Roque et al. (2004) reported forty-nine cases of Chironomidae larvae living on other animals in Brazilian freshwaters, including invertebrates and fishes. Biotic interactions such as commensalism and predator-prey relationships could be key factors in the maintenance of species diversity, especially in the tropics (Robinson 1978, RoHDe 1992).

\section{ACKNOWLEDGMENTS}

We thank Peter S. Cranston for identification of Corynoneura material and to Ole A. Sæther for his comments on Corynoneura taxonomy, A. Contreras-Ramos was contacted for Corydalus confirmation. We appreciated comments on an early version of the manuscript by Geraldo W. Fernandes, Paula Eterovick, Manuel A. Graça and Marcos S. Barbeitos. This study was supported by grants from the Fundação de Amparo à Pesquisa do Estado de Minas Gerais, Conselho Nacional de Pesquisa e Desenvolvimento (CNPq), Pró-reitorias de Graduação, Pesquisa e Extensão of the Universidade Federal de Minas Gerais, Instituto Brasileiro de Meio Ambiente, US Fish and Wildlife Service. M. Callisto and R.P. Martins received research scholarships from CNPq.

\section{REFERENCES}

Bush A.O., K.D. Lafferty; J.M. Lotz \& A.W. Shostak. 1997. Parasitology meets ecology on its own terms: Margolis et al. revisited. Journal of Parasitology, Washington, 83: 575583.

Callisto M. \& M. Goulart. 2000. Phoretic association between Nanocladius (Plecopteracoluthus) sp. (Chironomidae: Diptera) and Thraulodes sp. (Leptophlebiidae: Ephemeroptera) Anais da Sociedade Entomológica do Brasil, Curitiba, 29 (3): 1-4.

Callisto M.; M. Goulart; A.O. Medeiros; P. Moreno C.A. \& Rosa. 2004. Diversity assessment of benthic macroinvertebrates, yeasts, and microbiological indicators along a longitudinal gradient in Serra do Cipó, Brazil. Brazilian Journal of Biology, Rio de Janeiro, 64 (4): 743-755. 
DE LA Rosa, C.L. 1992. Phoretic associations of Chironomidae (Diptera) on Corydalidae (Megaloptera) in northwestern Costa Rican streams. Journal of the North American Benthological Society, New York, 11: 316-323.

Dorvillé L.F., J.L. Nessimian \& A.M. SANSEverino. 2000. First record of symphoresy between a nymph of a stonefly Kempnyia tijucana (Plecoptera; Perlidae) and a chironomid larva Nanocladius (Plecopteracoluthus) in the neotropics. Studies on Neotropical Fauna and Environment, Tubingen, 35 (2): 109-114.

Doucett, R.R.; D.J. Giberson \& G. Power. 1999. Parasitic association of Nanocladius (Diptera: Chironomidae) and Pteronarcys biloba (Plecoptera: Pteronarcyidae): insights from stable-isotope analysis. Journal of the North American Benthological Society, New York, 18 (4): 514-523.

Furnish J., D. Belluck; D. Baker \& B.A. Pennington. 1981. Phoretic relationships between Corydalus cornutus (Megaloptera: Corydalidae) and Chironomidae in eastern Tennessee. Annals of Entomological Society of America, New York, 74: 29-30.

Galdean N., F.A.R. Barbosa; M. Callisto; L.A. Rocha \& M.M.G.S.M. MARques. 1999a. A proposed typology for the rivers of Serra do Cipó (Minas Gerais, Brazil) based on the diversity of benthic macroinvertebrates and the existing habitats. Traveaux Museum Historie Naturale "Grigore Antipa", Bucharest, 41: 445-453.

Galdean N.; M. Callisto \& F.A.R. Barbosa. 1999b. Benthic macroinvertebrates of the head-waters of river São Francisco (National Park of Serra da Canastra, Brazil). Traveaux Museum Historie Naturale "Grigore Antipa", Bucharest, 41: 455-464.

Galdean N.; M. Callisto \& F.A.R. Barbosa. 2001. Biodiversity assessment of benthic macroinvertebrates in altitudinal lotic ecosystems of Serra do Cipó (MG - Brazil). Revista Brasileira de Biologia, Rio de Janeiro, 61 (2): 239-248.

Hayashi, F. 1988. Life-history variation in a dobsonfly, Protohermes grandis (Megaloptera, Corydalidae) - effects of prey availability and temperature. Freshwater Biology, Oxford, 19 (2): 205-2016.

JACOBSEN, R.E. 1998. The symbiotic relationship of a chironomid with its ephemeropteran host in an Arizona mountain stream. Journal of the Kansas Entomological Society, Kansas, 71: 426-438.

MANCINI, E.R. 1979. A phoretic relationship between a chironomid larva and an operculate stream snail. Entomological News, Ontario, 90: 33-36.

Margolis, L.; G.W. Esch; J.C. Holmes; A.M. Kuris \& G.A. Schad. 1982. The use of ecological terms in parasitology (report of an ad hoc committee of the American Society of Parasito- logists). Journal of Parasitology, Washington, 68 (1): 131133.

Pennuto, C.M. 1997. Incidence of Chironomid phoretics on Hellgrammites in streams of Southern Maine. Northeastern Naturalist, Maine, 4: 285-292.

Pennuto, C.M. 1998. Seasonal position patterns and fate of a commensal chironomid on its fishfly host. Journal of Freshwater Ecology, La Crosse, 13: 323-332.

Pennuto, C.M. 2000. Effects of larval density and movement behavior on emergence success of a midge commensal. Aquatic Ecology, New York, 34: 177-184.

Pennuto, C.M. 2003. Population dynamics and intraspecific interactions of an ectosymbiotic midge in a river in southern Maine, USA. Journal of the North American Benthological Society, New York, 22: 249-262.

Pennuto, C.M.; C.L. Wooster-Brown \& C.A. Belisle. 2002. Infestation intensity and prevalence of an ectosymbiotic midge under variable environmental and host conditions. Canadian Journal of Zoology, Ottawa, 80 (12): 2061-2071.

Rоваск, S.S. 1977. First record of a chironomid larva living phoretically on an aquatic hemipteran (Naucoridae). Entomological News, Ontario, 88: 192.

Robinson, M.H. 1978. Is tropical biology real? Tropical Ecology, Cambridge, 19 (1): 30-50.

RoHDE, K. 1992. Latitudinal gradients in species diversity: the search for the primary cause. Oikos, Lund, 65: 514-527.

Roque, F.O.; S. Trivinho-Strixino; M. Jancso \& E.N. Fragoso. 2004. Records of Chironomidae larvae living on other aquatic animals in Brazil. Biota Neotropica, São Paulo, 4 (2): 1-9.

Rosenberg, D. 1972. A chironomid (Diptera) larva attached to a libellulid (Odonata) larva. Quaestiones Entomologicae, Florida, 8: 3-4.

Steffan, A.W. 1967. Ectosymbiosis in aquatic insects, p. 207289. In: S.M. Henry (Ed.), Symbiosis. New York, Academic Press.

Svensson, B.S.1979. Pupation, emergence and fecundity of phoretic Epoicocladius ephemerae (Chironomidae). Holartic Ecology, Lund, 2: 41-50.

Tokeshi, M. 1986. Population ecology of the commensal chironomid Epoicocladius flavens on its mayfly host Ephemera danica. Freshwater Biology, Oxford, 16: 235-243.

Tokeshi, M. 1999. Species coexistence: ecological and evolutionary perspectives. Oxford, Blackwell Science, 245p.

White T.R.; J.S. Weaver III \& R.C. Fox. 1980. Phoretic relationships between Chironomidae (Diptera) and benthic macroinvertebrates. Entomological News, Ontario, 91 (3): 69-74.

Received in 07.VI.2005; accepted in 07.III.2006. 